\title{
Evaluation of tear film function, ocular surface and tear film in HIV-seropositive patients
}

\author{
Avaliação da função lacrimal, da superfície ocular e \\ do filme lacrimal em pacientes soropositivos para o HIV
}

Carolina Ramos Mosena', Marcus Vinicius Vieira Pinheiro', Paula Azevedo Alhadeff ${ }^{2}$, Thyarles Tomich Neiva ${ }^{3}$, Sérgio Felberg'

\begin{abstract}
Objective: Evaluate tear function, tear film and ocular surface in patients with positive serology for HIV. Methods: Observational, cross-sectional, quantitative and analytical study, performed between june and october 2011, in the HSPE-SP Ophthalmology Department, including 32 patients. Sixteen were HIV-positive patients and 16 HIV-negative. Results: There was no significant statistical difference in the middle age between both groups ( $\mathrm{p}=0.083$ ). The ferning test was statistically different in HIV group (with predominance of III and IV) compared to the control group (in which predominated the patterns I and II), both in the right and the left eye ( $p=0.019$ and $p<0.001$, respectively). Other parameters were not statistically significant between the groups. Conclusion: HIV-positive patients had no changes in lacrimal function and ocular surface, however, samples of tears showed differences considered statistically significant in the crystallization test, compared with samples obtained from controls.
\end{abstract}

Keywords: keratoconjunctivitis sicca; HIV; Dry eye

\section{RESUMO}

Objetivo: Avaliar a função lacrimal, a superfície ocular e o filme lacrimal de pacientes com sorologia positiva para o vírus HIV. Métodos: Estudo observacional, transversal, quantitativo e analítico, realizado entre junho e outubro de 2011, no Departamento de Oftalmologia do HSPE-SP, com 32 pacientes no total, sendo 16 soropositivos para o HIV e 16 soronegativos. Resultados: Não houve diferença estatística significante na média da idade entre os grupos estudados $(p=0,083)$. O padrão do teste de cristalização da lágrima foi estatisticamente diferente no grupo de pacientes HIV (com predomínio dos padrões III e IV) em relação ao grupo controle (no qual predominaram os padrões I e II), tanto no olho direito como no esquerdo ( $p=0,019$ e $p<0,001$, respectivamente). As demais variáveis estudadas não mostraram-se estatisticamente relevantes entre os grupos. Conclusão: Os pacientes soropositivos para o HIV não apresentaram alterações da função lacrimal e da superfície ocular, porém amostras de lágrimas evidenciaram diferenças consideradas estatisticamente significantes nos padrões dos testes de cristalização do filme lacrimal, quando comparadas com amostras obtidas de pacientes controles.

Descritores: Ceratoconjuntivite seca; HIV; Olho seco

\footnotetext{
${ }^{1}$ Cornea and External Diseases Division, Civil Servant Hospital "Francisco Morato de Oliveira", SP, Brazil.

2 Glaucoma Division, Civil Servant Hospital "Francisco Morato de Oliveira", SP, Brazil.

${ }^{3}$ Retina and Vitreous Division, Civil Servant Hospital "Francisco Morato de Oliveira", SP, Brazil.
}

Work done at the Civil Servant Hospital "Francisco Morato de Oliveira", SP, Brazil.

The authors declare no conflict of interest.

Received for publication 01/07/2014 - Accepted for publication 11/07/2014

Rev Bras Oftalmol. 2015; 74 (2): 81-8 


\section{INTRODUCTION}

A cquired immune deficiency syndrome (AIDS) was first acknowledged in the United States in the eighties, and it is accepted that the human immunodeficiency virus (HIV) originally came from apes in Africa ${ }^{(1,2)}$. The transmission of the retrovirus to humans may have occurred through bites, injuries or any contact with the blood of these animals. However, the AIDS pandemic followed the large scale use of apes in biology experiments, including xenotransplantation ${ }^{(3)}$.

According to data from the World Health Organization (WHO), there are about 33.3 million people infected with the HIV virus in the world, and in Brazil over 590 thousand cases were identified from 1980, when the HIV virus was discovered, to June $2010^{(4)}$.

The systematic classification for the definition of AIDS was proposed in 1982 by the Centers for Disease Control (CDC) and reviewed in 1997. Currently, the classification is based on the quantification of $\mathrm{T} C \mathrm{CD} 4+$ lymphocytes, since the decrease in numbers of this lymphocyte is one of the main characteristics of the disease ${ }^{(5,6)}$.

Regarding anterior segment ocular alterations in HIV, before the Highly Active Antiretroviral Therapy (HAART), Kaposi sarcoma was often seen, as well as Burkitt lymphoma, conjunctival microvasculopathy, nonspecific conjunctivitis, keratoconjunctivitis sicca and iridocyclitis. The main alterations in the posterior segment were cotton-wool spots, cytomegalovirus retinitis, herpes simplex and varicella zoster, HIV, toxoplasmosis, syphilitic retinitis and infectious endophthalmitis ${ }^{(7,8)}$.

As for external ocular diseases, several studies in HIVpositive patients report an important prevalence of dry eye among AIDS patients in the times before HAART ${ }^{(9,10)}$.

The dry eye syndrome refers to an ocular surface disease with several etiologies which often coexist. It is hard to accurately establish the prevalence of dry eye syndrome in a specific population due to the lack of clear diagnostic criteria and subjectivity of symptoms. For its diagnosis to be more objective, clinical trials are established, such as the evaluation of tear film break up test (TFBUT), surface staining with vital dyes (fluorescein, rose bengal and lissamine green), Schirmer's test and ferning test. Other tests, such as tear film osmolarity, tear film protein concentration measurement, interferometry and evaporimetry, are not very useful in daily use, due to poor convenience and its high cost.

In 2007, the results of the International Dry Eye Workshop $(D E W S)^{(11)}$ were published. Dry eye was defined as a multifactor tear film and ocular surface disease, causing discomfort, visual cloudiness and tear film instability, with potential harm to the ocular surface and associated to the increase in tear osmolarity and inflammation of the ocular surface.

The etiology of the dry eye associated with HIV is not well established yet, but tear reduction may be related to lymphocytic infiltration and potential destruction of acini and ducts in the lacrimal gland, which would present as a Sjögren-like syndrome, not only because of clinical aspects, but also because of the histopathology $y^{(12)}$. The prevalence of dry eye among HIV-positive patients in previous studies varied between $7.79 \%$ and $38.8 \%$, and dry eye symptomatology has an important impact on the quality of life of these patients ${ }^{(13-17)}$. At the very beginning of the HIV epidemic, SJ cases were notified as secondary to the infection
(18). However, a few years later, the sicca syndrome associated with HIV was defined as a clinical entity which was then named diffuse infiltrative lymphocytosis syndrome (DILS). Present in 0.85 to $3 \%$ of HIV-positive patients, DILS is characterized by lymphocytic infiltration in several organs and peripheral lymphocytosis due to CD8+, which manifests clinically as sicca syndrome and parotid growth, imitating a Sjögren syndrome presentation (Sjögren-like). The reduction in tear secretion may be tied to this lymphocytic infiltration and potential destruction of acini and ducts in the lacrimal gland ${ }^{(18)}$. In SJ, the lymphocytic infiltration occurs due to CD4+ and serology tests (anti-RO and anti-LA) are positive ${ }^{(19,20)}$.

\section{Овjective}

Evaluation of tear function, ocular surface and tear film in HIV-positive patients.

\section{Methods}

Observational, cross-sectional, quantitative and analytical study, performed between June and October 2011, in the HSPESP Ophthalmology Department. The work protocol was approved by the Ethics and Research Committee under protocol 079/11.

Two groups were defined and named "study group" and "control group".

\section{Study Group}

Inclusion criteria: positive serology for human immunodeficiency virus (HIV), legal age of majority and signing the consent form.

Exclusion criteria: positive serology for hepatitis B or C, use of ocular medication or contact lenses in the seven days prior to the assessment, previously diagnosed ocular diseases that affect lacrimal production or draining (Sjögren syndrome, StevensJohnson syndrome, ocular pemphigoid, ocular chemical burn, trachoma, peripheral facial paralysis), continuous use of medication with anticholinergic effect, pregnant and nursing women.

\section{Control Group}

Inclusion criteria: positive serology for human immunodeficiency virus (HIV), legal age of majority and signing the consent form.

Exclusion criteria: positive serology for hepatitis B or C, use of ocular medication or contact lenses in the seven days prior to the assessment, previously diagnosed ocular diseases that affect lacrimal production or draining (Sjögren syndrome, StevensJohnson syndrome, ocular pemphigoid, ocular chemical burn, trachoma, peripheral facial paralysis), continuous use of medication with anticholinergic effect, pregnant and nursing women.

According to the proposed criteria, 16 HIV-positive patients and 16 HIV-negative patients were selected.

In the Study Group, 5 patients were male and 11 female. The mean age was 44.94 years $( \pm 10.33)$. In the Control Group, 5 patients were male and 11 female and the mean age was 55.50 years $( \pm 20.81)$. Tables 1 and 2 , which summarize the data, show that there are no significant statistical differences between groups regarding either age $(\mathrm{p}=0.083)$ or gender $(\mathrm{p}>0.999)$. Table 3 summarizes study group patients data, including duration of HIV infection. 


\section{Exams sequence}

When looking it up in literature, we found no consensus regarding the ideal sequence for dry eye testing, so the proposal of this study was to avoid as much as possible that one test would influence the performance in the following test.

Both study group patients and control group patients followed the same examination sequence. To begin with, a standard questionnaire was applied, asking about known duration of infection and likely form of contamination, as well as, if applied, antiretroviral therapy in use.

After obtaining this information, parameters under study and interval between each exam are described below:

Table 1

\section{Assessment of groups regarding gender}

\begin{tabular}{|c|c|c|c|c|c|c|c|}
\hline \multirow{3}{*}{ Variable } & \multicolumn{4}{|c|}{ Group } & & & \multirow{3}{*}{ p-Value } \\
\hline & \multicolumn{2}{|c|}{ Control } & \multicolumn{2}{|c|}{ HIV+ } & \multicolumn{2}{|c|}{ Total } & \\
\hline & $\mathbf{n}$ & $\%$ & $\mathbf{n}$ & $\%$ & $\mathbf{N}$ & $\%$ & \\
\hline Gender & & & & & & & $>0.999 \#$ \\
\hline Female & 11 & 68.8 & 11 & 68.8 & 22 & 68.8 & \\
\hline Male & 5 & 31.3 & 5 & 31.3 & 10 & 31.3 & \\
\hline Total & 16 & 100 & 16 & 100 & 32 & 100 & \\
\hline
\end{tabular}

Table 2

- Assessment of groups regarding age

\begin{tabular}{lcccccccc}
\hline Variable & Group & Average SD & Mean & Min & Max & N & p-Value \\
\hline Age & Control & 55.50 & 20.81 & 55.5 & 18 & 85 & 16 & 0.083 \\
(years) & HIV+ & 44.94 & 10.33 & 44 & 18 & 72 & 16 &
\end{tabular}

Table 3

Study group data (HIV+)

\begin{tabular}{cccc}
\hline Patient & Gender & Age & st Infection \\
\hline 1 & F & 46 & 132 \\
2 & M & 41 & 7 \\
3 & F & 44 & 96 \\
4 & M & 43 & 96 \\
5 & M & 41 & 120 \\
6 & M & 51 & 168 \\
7 & F & 50 & 168 \\
8 & M & 50 & 24 \\
9 & F & 45 & 156 \\
10 & F & 72 & 228 \\
11 & F & 43 & 144 \\
12 & F & 42 & 108 \\
13 & F & 44 & 168 \\
14 & F & 18 & 84 \\
15 & F & 43 & 84 \\
16 & F & 46 & 168 \\
\hline
\end{tabular}

Legend: $\mathrm{F}=$ female; $\mathrm{M}=$ male; age=in years; $\Delta \mathrm{t}$ Infection= in months
To begin with, "specific-dry eye" questionnaire was applied: Ocular Surface Disease Index ${ }^{\circledR}$ (OSDI); immediately afterwards, a tear sample was collected for the tear ferning test; afterwards, tear film break-up time was observed and the cornea was examined with fluorescein dye $1 \%$. At least thirty minutes after the previous test, Schirmer's test I was performed. Ocular surface was studied again after this, but this time rose bengal dye 1\% was used. Finally, at least thirty minutes after the previous test, cornea sensitivity was examined with Cochet-Bonet esthesiometer.

\section{Exams site}

Questionnaire application, tear film break-up time measures, ocular surface staining with fluorescein $1 \%$ dye, Schirmer's test I, ocular surface staining with rose bengal dye $1 \%$, esthesiometry and tear sample collection were all performed in the same room at the Cornea and External Diseases Outpatient Station at the IAMSPE Ophthalmology Department, with doors and windows closed.

At collection times, temperature and relative humidity inside the room were recorded with a digital thermo-hygrometer (Barigo ${ }^{\circledR}$, Barometerfabrik, Villingen-Schwenningen, Germany). The device records, for a set period, minimum and maximum temperature, as well as minimum and maximum relative humidity. Table 4 shows the summary of measures recorded on the days patients were examined.

\section{Table 4}

Record of temperature values $\left({ }^{\circ} \mathrm{C}\right)$ and relative humidity $(\%)$

\begin{tabular}{lrccc}
\hline & T. $\min { }^{\circ} \mathbf{C}$ & T. $\max ^{\circ} \mathbf{C}$ & R.H. $\min \%$ & R.H. $\max \%$ \\
\hline Minimum & 20.7 & 21.9 & 43 & 49 \\
Maximum & 23.2 & 25.8 & 68 & 73 \\
Average & 22.05 & 23.8 & 53.5 & 60.6 \\
SD & 0.96 & 1.54 & 7.81 & 7.52 \\
\hline
\end{tabular}

Legend: $\mathrm{T} .=$ temperature; $\mathrm{R} . \mathrm{H} .=$ relative humidity; $\min .=$ minimum; max. $=$ maximum $; \mathrm{SD}=$ standard deviation

\section{Parameters description}

\section{- OSDI questionnaire}

All patients were submitted to the "Ocular Surface Disease Index" specific-dry eye questionnaire (OSDI ${ }^{\circledR}$, Allergan, Irvine, California, EUA), composed of twelve questions asked of patients by the researcher. To answer them, they were to consider the seven days prior to the interview. Questions over three areas: ocular symptoms, possible environmental stimuli causing ocular discomfort, and finally, daily routine limitations due to patients' ocular clinical condition. To measure the intensity of answers given, patients allot each question with an answer on a scale of 0 to 4 points, with 0 representing minimum commitment and 4 maximum commitment. A global score is given at the end, considering both indexes for each answer and the total number of questions which could be answered. This score varies from 0 to 100 , with 0 meaning lack of ocular discomfort and 100 meaning maximum ocular discomfort. The questionnaire was applied to patients in all phases by the same researcher (CM). 


\section{- Ferning test}

In this type of examination, known as ferning test, patients were settled into the slit lamp and a tear sample was collected from the bottom of the right eye lacrimal sac with a nonheparinized capillary glass tube. A drop with diameter varying from two to three millimeters was deposited on the surface of a clean glass slide, at the center of a circle previously marked with blue or red ink. The tear was allowed to dry at room temperature for about ten minutes before being stored properly for transportaiton. Slide observation occurred afterwards, with a common optical microscope, Zeiss Axistar, which took digital pictures of the site corresponding to the dry tear with a camera attached to the microscope (Sony Cybershot ${ }^{\grave{D}}$ DSC-W120 model), in increases of 5, 10 and 40 times and 3 megapixels resolution. Material collection and picture taking were carried out by the same researcher $(\mathrm{CM})$. Pictures were examined at a different time and independently by another researcher with prior experience in reading the test (SF).

The findings of the ferning test were classified into four types, according to the model proposed by Rolando, in which types I and II were considered normal and types II and IV were considered abnormal ${ }^{(21)}$.

\section{- Tear film break-up time (TFBUT)}

The exam was performed with a slit lamp and cobalt blue light. A drop of fluorescein 1\% was instilled into the bottom sac of both of the patients' eyes. Patients were asked to blink a few times and then stop, when the stopwatch was immediately activated. The study observed how long it took for the first tear film break-up point to show at the corneal surface. Three measures were taken to obtain the mean time.

The exam was performed in all phases by the same researcher $(\mathrm{CM})$.

\section{- Corneal exam with fluorescein dye $1 \%$}

Using the same fluorescein volume instilled to verify the TFBUT, the cornea of each eye was examined immediately afterwards according to the following score proposed by researchers:

Score 0: no corneal alteration; not stained by fluorescein. the dye.

Score 1: dotted keratitis, with sparse dots highlighted by

Score 2: dotted keratitis, with close dots highlighted by the dye.

Score 3: intense keratitis, with confluent dots highlighted by the dye.

The exam was performed in all phases by the same researcher (CM).

\section{- Schirmer's Test I}

Schirmer's test I, also called Schirmer's test without topical anesthetics, was performed simultaneously on both eyes, inserting a standardized millimeter Wathmann filter paper strip size 41 into the third corner of each lower eyelid (Ophthalmos ${ }^{\hat{a}}$, São Paulo, Brazil). Patients were asked to keep their eyes closed for five minutes. The value that corresponded to the moisture on the paper in each eye was then observed and written down.

The exam was performed in all phases by the same researcher $(\mathrm{CM})$.

\section{- Ocular surface examination with rose bengal dye 1\%}

The examination of injury caused to the ocular surface was analyzed with rose bengal dye $1 \%$.A drop of dye was instilled into the superior bulbar conjunctiva of both of the patients' eyes. They were then examined in the slit lamp with green filter and light. The eyes were classified according to van Bjesterveld's proposal ${ }^{(22)}$, in which each eye has the ocular surface exposed by the naturally open slit, divided into three parts: lateral bulbar conjunctiva, cornea and medium bulbar conjunctiva. Each part gets a score from the examiner that goes from 0 to 3 :

Score 0: doesn't stain with rose bengal.

Score 1: stains lightly, with sparse points.

Score 2: stains moderately, with near points.

Score 3: stains intensely, with confluent points.

The scores of all three parts are added for a final score that goes from 0 to 9 points, where 0 is considered a lack of injury to the surface and 9 is maximum injury. The exam was performed in all phases by the same researcher (CM).

\section{- Esthesiometry}

In the central corneal sensitivity examination, the patient informed the minimum sensitivity to touch when stimulated in the central area of the cornea by the Cochet-Bonnet esthesiometer (Luneau Ophthalmologie, Paris-France), according to standardization proposed by Norn ${ }^{(23)}$. The exam was performed in both eyes, always by the same examiner (CM), who started testing on the right eye, touching the central cornea with maximum exposure of the nylon filament (level 6). If the touch wasn't noticed, the filament was retracted to level 5.5 and so on, in increments of 0.5 , until level 0 was reached. When the touch was noticed, the value corresponding to the filament exposure level was recorded.

\section{Statistical analysis}

To be able to fulfill the objectives of the study, first the measures analyzed were described in groups by using summarizing measures (average, standard deviation, mean, minimum and maximum) and the values were compared between groups by using Mann-Whitney tests, except for age, which was compared using a t-Student test.

Gender, OSDI and ferning classifications were described in groups by using absolute and relative frequencies and verified existing association between gender and groups by using chisquare test and comparing the degrees of scales between groups by using Mann-Whitney tests.

Tests were performed with a 5\% significance level.

\section{Results}

Table 5 shows that the mean age for the control group is statistically the same as the HIV+ group $(\mathrm{p}=0.083)$ and tests which have scores (fluorescein and rose bengal) were also no different statistically between control and HIV+ groups $(\mathrm{p}>0.05)$.

On Table 6 it is possible to see that the ferning test pattern is statistically different in the HIV+ group (types III and IV are prevalent) in relation to the control group (in which types I and II are prevalent) both for the right and the left eye ( $\mathrm{p}=0.019$ and $\mathrm{p}<0.001$, respectively).

Graphs 1 and 2 illustrate the results of Table 5, and ferning test scores for both eyes were statistically higher in $\mathrm{HIV}+$ patients. 
Table 5

Description of numerical scale values according to groups and comparative test results

\begin{tabular}{|c|c|c|c|c|c|c|c|c|}
\hline Variable & Group & Average & SD & Mean & Minimum & Maximum & $\mathbf{N}$ & p-Value \\
\hline \multirow[t]{2}{*}{ Age (years) } & Control & 55.50 & 20.81 & 55.5 & 18 & 85 & 16 & $0.083^{*}$ \\
\hline & $\mathrm{HIV}+$ & 44.94 & 10.33 & 44 & 18 & 72 & 16 & \\
\hline \multirow[t]{2}{*}{ Absolute OSDI } & Control & 13.79 & 17.13 & 7.15 & 0 & 70 & 16 & 0.926 \\
\hline & $\mathrm{HIV}+$ & 13.18 & 13.16 & 7.67 & 0 & 41.6 & 16 & \\
\hline \multirow[t]{2}{*}{ BUT RE (seconds) } & Control & 7.94 & 2.67 & 10 & 3 & 10 & 16 & 0.224 \\
\hline & $\mathrm{HIV}+$ & 6.56 & 3.27 & 7 & 2 & 10 & 16 & \\
\hline \multirow[t]{2}{*}{ BUT LE (seconds) } & Control & 7.81 & 2.59 & 9 & 3 & 10 & 16 & 0.224 \\
\hline & $\mathrm{HIV}+$ & 6.31 & 3.26 & 5 & 2 & 10 & 16 & \\
\hline \multirow[t]{2}{*}{ Schirmer RE (mm) } & Control & 14.81 & 9.84 & 15 & 2 & 35 & 16 & 0.838 \\
\hline & $\mathrm{HIV}+$ & 15.56 & 9.75 & 14.5 & 1 & 35 & 16 & \\
\hline \multirow[t]{2}{*}{ Schirmer LE (mm) } & Control & 15.25 & 8.24 & 13.5 & 6 & 35 & 16 & 0.809 \\
\hline & HIV+ & 15.25 & 9.83 & 11.5 & 3 & 35 & 16 & \\
\hline \multirow[t]{2}{*}{ Esthesiometry RE } & Control & 5.13 & 0.81 & 5.5 & 3.5 & 6 & 16 & 0.171 \\
\hline & $\mathrm{HIV}+$ & 4.34 & 1.55 & 4.5 & 1 & 6 & 16 & \\
\hline \multirow[t]{2}{*}{ Esthesiometry LE } & Control & 5.25 & 0.71 & 5.5 & 3.5 & 6 & 16 & 0.210 \\
\hline & HIV+ & 4.41 & 1.54 & 4.75 & 1.5 & 6 & 16 & \\
\hline \multirow[t]{2}{*}{ Fluor RE } & Control & 0.19 & 0.54 & 0 & 0 & 2 & 16 & 0.752 \\
\hline & $\mathrm{HIV}+$ & 0.06 & 0.25 & 0 & 0 & 1 & 16 & \\
\hline \multirow[t]{2}{*}{ Fluor LE } & Control & 0.19 & 0.54 & 0 & 0 & 2 & 16 & 0.780 \\
\hline & $\mathrm{HIV}+$ & 0.25 & 0.58 & 0 & 0 & 2 & 16 & \\
\hline \multirow[t]{2}{*}{ Rose RE } & Control & 0.13 & 0.34 & 0 & 0 & 1 & 16 & $>0.999$ \\
\hline & $\mathrm{HIV}+$ & 0.13 & 0.34 & 0 & 0 & 1 & 16 & \\
\hline \multirow[t]{2}{*}{ Rose LE } & Control & 0.19 & 0.40 & 0 & 0 & 1 & 16 & 0.780 \\
\hline & HIV+ & 0.25 & 0.45 & 0 & 0 & 1 & 16 & \\
\hline
\end{tabular}

Mann-Whitney test result * t-Student test result

Table 6

Description of qualitative scales according to groups and association test results and comparative scales test

\begin{tabular}{|c|c|c|c|c|c|c|c|}
\hline \multirow{3}{*}{ Variável } & \multicolumn{4}{|c|}{ Group } & & & \multirow{3}{*}{ p-Value } \\
\hline & \multicolumn{2}{|c|}{ Control } & \multicolumn{2}{|c|}{$\mathrm{HIV}+$} & \multicolumn{2}{|c|}{ Total } & \\
\hline & $\mathbf{n}$ & $\%$ & $\mathbf{n}$ & $\%$ & $\mathbf{N}$ & $\%$ & \\
\hline OSDI classification & & & & & & & 0.809 \\
\hline Normal & 11 & 68.8 & 12 & 75,0 & 23 & 71.9 & \\
\hline Light & 2 & 12.5 & 1 & 6,3 & 3 & 9.4 & \\
\hline Moderate & 3 & 18.8 & 3 & 18.8 & 6 & 18.8 & \\
\hline Crystal RE & & & & & & & 0.019 \\
\hline I & 6 & 37.5 & 2 & 12.5 & 8 & 25.0 & \\
\hline II & 6 & 37.5 & 3 & 18.8 & 9 & 28.1 & \\
\hline III & 3 & 18.8 & 7 & 43.8 & 10 & 31.3 & \\
\hline IV & 1 & 6.3 & 4 & 25.0 & 5 & 15.6 & \\
\hline Crystal LE & & & & & & & $<0.001$ \\
\hline I & 10 & 62.5 & 2 & 12,5 & 12 & 37.5 & \\
\hline II & 4 & 25,0 & 1 & 6.3 & 5 & 15.6 & \\
\hline III & 2 & 12.5 & 5 & 31.3 & 7 & 21.9 & \\
\hline IV & 0 & 0.0 & 8 & 50.0 & 8 & 25.0 & \\
\hline Total & 16 & 100 & 16 & 100 & 32 & 100 & \\
\hline
\end{tabular}




\section{Chart 1} Percentage of crystallization in the right eye
observed according to groups.

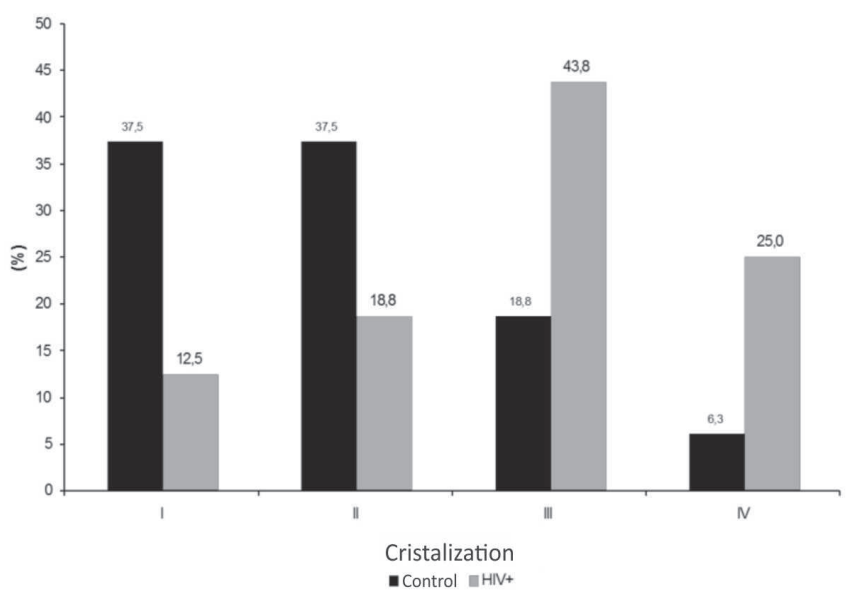

Chart 2

\section{Percentage of crystallization in the left eye observed according to groups}

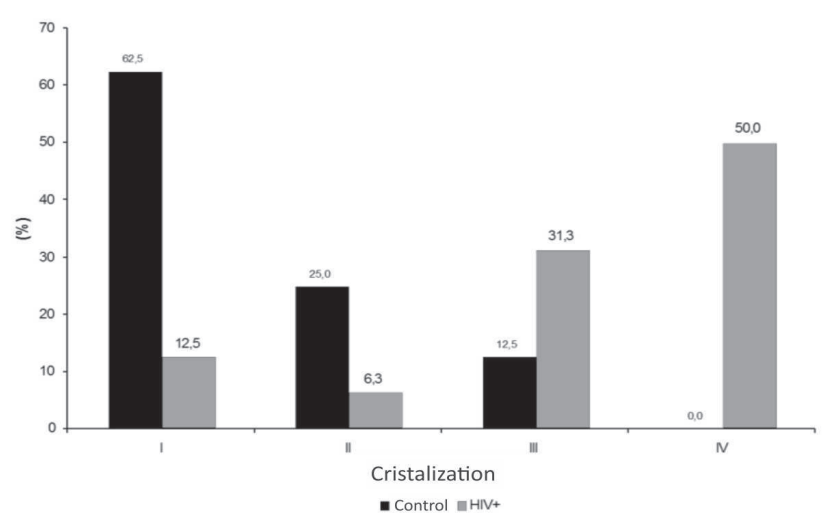

\section{Discussion}

Data presented in this study has shown that analysis of tear function tests (Schirmer's test and ferning test) and ocular surface status (fluorescein and rose bengal dye exams and corneal sensitivity) of HIV-positive patients do not show significant difference in relation to control patients under conditions studied. Some issues restrict data interpretation, including the small sample of patients in the study group, the heterogeneity of the time between the viral infection and the ocular examination and individual characteristics of the antiretroviral treatment and the clinical status due to HIV contamination. At first we planned to describe our findings using the full number of eyes (64 eyes), however, since the disease under study affects both eyes in a similar manner, we chose to use the number of patients, rather than eye, though both eyes were submitted to all tests. Therefore, finding a lack of alterations that would indicate keratoconjunctivitis sicca in the study group allows us to conclude only that the selected patients in the group did not present with dry eye at the exact moment our examination was performed, unlike other researchers' findings.
If we admit that the clinical condition of ocular dryness associated with HIV infection observed by other authors does in fact resemble that of Sjögren's syndrome, it is possible to conclude that injuries caused to the exocrine tissue will also occur progressively to the first group, with slow and gradual onset of symptoms. Therefore it is not possible to rule out the possibility that the group under study will eventually develop tear function alterations and as a consequence, ocular surface alterations, so it would be advisable to examine those patients periodically.

The etiology of keratoconjunctivitis sicca related to HIV infection is not well established yet. Evidence from studies with Sjögren's syndrome patients show the presence of crossreaction between serum antibodies and retroviral proteins, as well as the occurrence of reverse transcriptase activity in the salivary glands ${ }^{(18)}$. Besides, the detection of retroviral antigens, retrovirus-like particles or retroviral sequences in the salivary glands of patients with retrovirus systemic infection (EBV, HIV and HTLV) support the theory that the infection could be the trigger for the development of symptoms caused by the hypoactivity of exocrine glands, although so far, no study has proved that the findings in the salivary glands are reproduced in lacrimal glands, though clinical evidence indicates that the pathogenic mechanism is similar ${ }^{(24)}$.

Both the presence of the live virus in the glandular microenvirnoment and the immunologic dysfunction that causes the defense system to consider non-self proteins from gland ducts and acini in a cross-reaction with viral proteins may cause inflammation and local destruction, explaining tear function abnormalities already described and observed by other authors in HIV-positive patients. That means, therefore, that some HIV infected patients who develop dry eye are, in fact, genetically predisposed to the cross-reaction, and we do not know exactly what percentage represents the group who develop dry eye through this mechanism in the universe of HIV-positive patients. It is possible to believe that in those cases, keratoconjunctivitis sicca sets in later than in those which are determined solely due to the virus being present in the acinar tissue. The small patient sample in this study favors the selection bias, so the group may have been composed of patients who are predisposed to long term alterations.

Rodrigues et al. observed a significant increase in dry eye syndrome in patients with over four years of evolution of their disease, especially among those who were using HAART, but the decrease in tear production was not related to severity or time of infection ${ }^{(25)}$. In the group we studied, all patients were using HAART and infection time was not taken into consideration, however, we did not find this relevant because we did not observe differences between the control group and them. If alterations in test performance were noticed in the infected group, there would be doubts about whether the use of systemic medication might be responsible for the findings. It may be assumed that the HAART regime might eliminate symptoms of a Sjögren-like syndrome, however, no study has clearly shown the performance of antiretrovirals, individually or combined, or whether they may have a harmful effect on one of the components of the tear film, regardless of the infection. On the other hand, in order to conclude if antiretroviral therapy factors in the prevention of keratoconjunctivitis sicca, something that may have occurred in patients in our study, a new study will be necessary, comparing HIV-positive patients under treatment with patients who have never had treatment and have no systemic comorbidities. 
Once again, samples tend to be small due to the frequent association of HIV infection with other viruses which may potentially trigger dry eye, among them HVC and HVB (which were exclusion criteria for the current study, and one of the causes of the small sample size).

Colombo et al. described the dissociation between dry eye signs and symptoms in patients with Sjögren's syndrome, that is, the weak relation between intensity of complaints (also assessed by the dry eye specific questionnaire, OSDI) and ocular surface status, especially in chronic and severe cases ${ }^{(26)}$. One of the explanations suggested by the authors was the the chronic inflammation caused by dry eyes and the local release of inflammatory mediators would cause corneal hypoesthesia, and consequent reduction of the perception of discomfort, despite having a much altered ocular surface. We believe, however, that normal values observed in the OSDI questionnaire in our study indicating a lack of ocular discomfort represent in fact a lack of complaints due to an absence of ocular injury, which was verified by the sequence of other tests and proved by the normal sensitivity of the examined corneas.

It may be possible that biochemical alterations of the tear film, responsible for the mucous component, in some conditions may be early symptoms of tear dysfunction, rather than the validation of aqueous production deficit or even of the presence of ocular surface injuries. This explains the lack of alterations in Schirmer's test. In the ferning test, we observed that HIV-infected patients tend to show poorer quality than normal patients. HIVpositive patients show Rolando types III and IV more often than individuals without the infection. Types I and II were more prevalent in those. Relative humidity over $50 \%$ may decrease test reproducibility, but early studies describing this test don't measure relative humidity and don't mention it as a parameter of influence (27), while other studies geared towards analyzing solely this test performed with relative humidity between 48$69 \%{ }^{(28)}$. The ferning test classification system works as an assessment index of tear film global quality, since for each of the types considered in classification to be formed, mucus, glycoprotein and electrolyte concentrations are decisive.

Another important test, not performed in our study, is the tear film osmolarity measure. We know that hyperosmolarity is a key mechanism in the physiopathogenesis of dry eye, having already been proved in several studies and being more and more discussed ${ }^{(29)}$. Hyperosmolarity occurs due to the reduction in aqueous production and/or increase in tear evaporation. It is also responsible for the reduction of caliciform cell density in the bulbar conjunctiva. The loss of caliciform cells may be responsible for the unstable tear film and mucin reduction ${ }^{(30)}$, highlighting an alteration in the biochemical component of the tear. Just like the ferning test, since it examines the first component to be affected in Sjögren-like cases, the osmolarity measure would also be altered in our study.

This finding supports the need for a follow up on this study, with new examinations of observed patients, under the same conditions described here, as well as a broader scope with different tests, like tear osmolarity measure in this group.

\section{Conclusion}

In the conditions studied, HIV-positive patients did not show tear function alterations or ocular surface alterations, however, tear samples highlighted differences which are considered statistically significant in ferning test standards, when compared to samples obtained from patients in the control group.

\section{References}

1. Bacchetti P, Moss AR. Incubation period of AIDS in San Francisco. Nature. 1989;338(6212):251-3.

2. McClure MO, Schulz, TF. Origin of HIV. BMJ. 1989;298 (6883): 1267-8.

3. Mendes NF. Simian viruses, organ xenotransplantation and a hypothesis about the origin of AIDS. Braz J Med Biol Res. 1993; 26(3):231-3.

4. UNAIDS. Resumo mundial da epidemia de HIV/SIDA - janeiro de 2011 [Interne]. [mentioned 2014 Sept 30]. Available at: URL: http://www.unaids.org.

5. Garry RF. Potential mechanisms for the cytopathic properties of HIV. AIDS. 1989;(11):683-94.

6. Update: acquired immunodeficiency syndrome - United States, 1992. MMWR Morb Mortal Wkly Rep. 1993; 42(28):547-51,557.

7. Freitas JA, Soranz Filho JE, Soranz JF, Barbosa ML, Gonçalves VL. Achados oftalmológicos em pacientes com Síndrome de Imunodeficiência Adquirida. Rev Bras Oftalmol. 1997;56(11):837-41.

8. Kadhem M; Kalisch SB, Goldsmith J, Fetkenhour C, O'Grady RB, Phair JP, Chrobak M. Ophthalmologic findings in acquired immunodeficiency syndrome (AIDS). Arch Ophthalmol. 1984;102(2):201-6.

9. Raskin RH, Justo DM, Torres LM, Picetti E, Cattani S, Bocaccio FJL, Rymer S. Avaliação de olho seco em pacientes com teste anti-HIV positivo [resumo]. Arq Bras Oftalmol. 1993;56(4).

10. Steck AD, Abreu MT, Muccioli C, Lottenberg C, Belfort Júnior R. Prevalência de olho seco em população de pacientes HIV positivos [resumo]. Arq Bras Oftalmol. 1994;57(4).

11. The definition and classification of dry eye disease: report of the definition and Classification Subcommittee of the International Dry Eye Workshop (2007). Ocul Surf. 2007;5(2):75-92.

12. Pflugfelder SC, Wilhelmus KR, Osato MS, Matoba AY, Font RL. The autoimmune nature of aqueous tear deficiency. Ophthalmology. 1986; 93(12):1513-7.

13. Kordossis T, Paikos S, Aroni K, Kitsanta P, Dimitrakopoulos A, Kavouklis E, et al. Prevalence of Sjögren-like syndrome in a cohort of HIV-1 positive patients: descriptive pathology and im munopathology. Br J Rheumatol. 1998: 37;(6):691-5.

14. DeCarlo DK, Penner SL, Schamerloh RJ, Fullard RJ. Dry eye among males infected with the human immunodeficiency virus. J Am Optom Assoc. 1995; 66(9):533-8.

15. Geier SA, Libera S, Klauss V, Goebel FD. Sicca syndrome in patients infected with the human immunodeficiency virus. Ophthalmology. 1995; 102(9):1319-24.

16. Lucca JA, Kung JS, Farris RL: Keratoconjunctivitis sicca in female patients infected with human immunodeficiency virus. CLAO J. 1994; 20(1):49-51.

17. Lucca JA, Farris RL, Bielory L, Caputo AR. Keratoconjunctivitis sicca in male patients infected with human immunodeficiency virus type 1. Ophthalmology.1990; 97(8):1008-10.

18. Sipsas NV, Gamaletsou MN, Moutsopoulos HM. Is Sjögren's syndrome a retroviral disease? Arthritis Res Ther. 2011; 13(2):212-19.

19. Panayiotakopoulos GD, Aroni K, Kyriaki D, Paikos S, Vouyioukas N, Vlachos A, Kontos AN, Kordossis T: Paucity of Sjögren's -like syndrome in a cohort of HIV-1-positive patients in the HAART era. Part II. Rheumatology (Oxford). 2003; 42(10):1164-7.

20. Felberg S, Dantas PE. Diagnóstico e tratamento da síndrome de Sjögren. Arq Bras Oftalmol. 2006; 69(6):959-63. 
21. Rolando M. Tear mucus ferning test in normal and keratoconjuntivitis sicca eyes. Chibret Int J Ophthamol. 1984; 2(4):32-41.

22. van Bijsterveld OP. Diagnostic tests in the Sicca syndrome. Arch Ophthalmol. 1969 Jul;82(1):10-4.

23. Norn MS. Conjuntival sensivity in pathological cases, with simultaneous measurement of corneal and lid margin sensitivity. Acta Ophthlmol (Copenh). 1975; 53(3):450-7.

24. Talal N, Dauphinée MJ, Dang H, Alexander SS, Hart DJ, Garry RF. Detection of serum autoantibodies to retroviral proteins in patients with primary Sjögren's syndrome (autoimmune exocrinopathy). Arthritis Rheum. 1990;33(6):774-781.

25. Rodrigues ML, Rodrigues ML, Holanda de Freitas JA. Estudo da síndrome de ceratoconjuntivite seca de pacientes soropositivos para o vírus da imunodeficiência adquirida humana tipo 1 e com síndrome da imunodeficiência adquirida, em uso ou não de terapia anti-retroviral combinada (HAART). Arq Bras Oftalmol. 2004; 67(2):283-7.

26. Barboza MN, Barboza GN, de Melo GM, Sato E, Dantas MC, Dantas PE, Felberg S. Correlation between signals and symptoms of dry eye in Sjögren's syndrome patients. Arq Bras Oftalmol. 2008;71(4):547-52.
27. Tabbara KF, Okumoto M. Ocular ferning test. A qualitative test for mucous deficiency. Ophthalmology. 1982; 89(6):712-4.

28. Felberg S, Cordeiro H, Sato E, Martini D, Dantas MC, Endo RM, Dantas PE. Reprodutibilidade na classificação do teste de cristalização do filme lacrimal em pacientes com síndrome de Sjögren. Arq Bras Oftalmol. 2008;71(2):228-33.

29. Baudouin C, Aragona P, Messmer EM. Role of hyperosmolarity in the pathogenesis and management of dry eye disease: proceedings of the OCEAN Group Meeting. Ocul Surf 2013;11(4):246-58.

30. Liu H, Begley C, Chen M, Bradley A, Bonanno J, McNamara NA, et al. A link between tear instability and hyperosmolarity in dry eye. Invest Ophthalmol Vis Sci. 2009; 50(8):3671-9.

\section{Corresponding author:}

Carolina Ramos Mosena

R Borges Lagoa, 1755 - Oftalmologia, $3^{\circ}$ andar - Vila Clementino CEP 704038-034. São Paulo - SP - Brasil

Phone: (11) 5549-2937 - (11) 5088-8167 - Fax: (11) 5549-2937

E-mail: carolmosena@hotmail.com 